\title{
Peningkatan Pemahaman Mengenai Larangan Rangkap Jabatan bagi Pengurus Lembaga Pemberdayaan Masyarakat Berdasarkan Peraturan Menteri Dalam Negeri Nomor 18 Tahun 2018 di Kecamatan Kulim
}

\author{
Eddy Asnawi*1, Andrizal ${ }^{2}$, Birman Simamora ${ }^{3}$, Alexsander Yandra ${ }^{4}$ \\ 1,2,3 Fakultas Hukum, Universitas Lancang Kuning \\ ${ }^{4}$ Fakultas Ilmu Administrasi Negara, Universitas Lancang Kuning \\ *e-mail: eddyasnawi@yahoo.com¹, Andrizal2017@gmail.com² , birman@unilak,ac.id³ , alexsy@unilak.ac.id ${ }^{4}$
}

\begin{abstract}
The partner problem is that many administrators of Community Empowerment Institutions in the Kulim sub-district do not yet know and understand the prohibition of concurrent positions for the management of Community Empowerment Institutions based on Minister of Home Affairs Regulation Number 18 of 2018 concerning Village Community Institutions and Village Traditional Institutions. The target of community service is to increase knowledge and understanding of Duties, Functions and Prohibitions for administrators. The output plans for this service activity are from drafts of scientific articles and mass media publications. The solution offered and agreed upon by the proposer and partners in overcoming the problem is that socialization needs to be conducted in legal counselling and discussion. The implementation method uses lectures and discussions. Lecturers deliver material, and participants are freed to have an interactive dialogue to obtain input in the form of problems, aspirations, proposals, ideas and solutions. Partners' participation in this activity is willing, provides time and place, and mobilizes the community as the target audience. The outputs that will be produced according to this community service activity plan are: for partners, of course, increasing knowledge and understanding of the duties, functions and prohibitions of management, for proposing the output to be achieved is in drafts of scientific articles.
\end{abstract}

Keywords: Prohibition, Multiple, Position.

\begin{abstract}
Abstrak
Permasalahan mitra adalah, banyak pengurus Lembaga Pemberdayaan Masyarakat dikelurahan sekecamatan Kulim belum mengetahui dan memahami mengenai larangan rangkap jabatan bagi pengurus Lembaga Pemberdayaan Masyarakat berdasarkan Peraturan Menteri Dalam Negeri Nomor 18 Tahun 2018 Tentang Lembaga Kemasyarakatan Desa dan Lembaga Adat Desa. Target pengabdian kepada masyarakat ini meningkat pengetahuan dan pemahaman mengenai Tugas, Fumgsi dan Larangan bagi pengurus. Adapun rencana luaran dari kegiatan pengabdian ini adalah berupa draft artikel ilmiah dan publikasi media massa. Solusi yang ditawarkan dan di sepakati oleh pihak pengusul dan mitra dalam mengatasi persoalan adalah perlu dilakukan sosilalisasi dalam bentuk penyuluhan hukum dan diskusi. Metode pelaksanaan menggunakan ceramah dan diskusi. Penceramah menyampaikan materi, peserta dibebaskan untuk berdialog interaktif untuk memperoleh masukan berupa persoalan, aspirasi, usulan, gagasan dan solusi. Partisipasi mitra dalam kegiatan ini bersedia, menyediakan waktu dan tempat, serta memobilisasi para masyarakat sebagai khalayak sasaran. Luaran yang akan dihasilkan sesuai rencana kegiatan pengabdian kepada masyarakat ini adalah : bagi mitra tentunya peningkatan pengetahuan dan pemahaman mengenai tugas, fungsi dan larangan pengurus, bagi pengusul luaran yang akan dicapai adalah berupa draft artikel ilmiah.
\end{abstract}

Kata kunci: Larangan, rangkap, jabatan.

\section{PENDAHULUAN}

Kulim merupakan salah satu pengembangan dari wilayah Tenayan Raya yang cukup luas dan pada disahkan pada akhir tahun 2020 yang terdiri dari kelurahan Sialang Rampai, Pebatuan, Kulim, Mentangor, dan Pematang Kapau. Dalam menjalankan roda pemerintahan pada semua tingkatan dalam rangka usaha mewujudkan kesejahteraan masyarakat yang aman dan damai, perlu partisipasi aktif dan dukungan positif dari semua komponen setempat agar usaha tersebut dapat lebih termaksimalkan, maka perlu dibangun sebuah sinergi dan harmonisasi dari semua komponen masyarakat. Dalam hal ini, Lembaga Kemasyarakatan, yang salah satu jenisnya berdasarkan regulasi yang berlaku adalah Lembaga Pemberdayaan Masyarakat yang disingkat dengan LPM, disamping yang lainnya seperti RT, RW, PKK, Karang Taruna, dan Posyandu. 
Disamping jenis lembaga kemasyarakatan diatas, pemerintah dan masyarakat dapat membentuk yang lainnya sesuai dengan perkembangan dan kebutuhan, Lembaga Pemberdayaan Masyarakat bertugas dan berfungsi menyerap dan menyalurkan keinginan dan kebutuhan substansi masyarakat yang dituangkan dalam sarana dan forum tersedia untuk itu. Yandra (2016) menjelaskan bahwa masyarakat merupakan subjek sekaligus objek dari pembangunan, untuk itu masyarakat luas mesti diikutsertakan dalam pembangunan tersebut sebab tujuan akhir yang akan dicapai adalah kesejahteraan itu sendiri. Terkait perencanaan pembangunan dan menggerakkan pembangunan dengan swadaya gotong royong, serta pelayanan umum lainnya.

Pengurus Lembaga Pemberdayaan Masyarakat dilarang rangkap jabatan pada lembaga kemasyarakatan lain, dan dilarang menjadi anggota parpol, namun dalam kenyataannya banyak pengurus di kelurahan se-kecamatan kulim yang rangkap jabatan dan menjadi anggota bahkan pengurus parpol, tidak tertutup kemungkinan juga terjadi dikecamatan lainya di kabupaten dan kota yang ada di provinsi Riau.

\section{Permasalahan Mitra}

Permasalahan mitra dalam hal ini khalayak sasaran Pengabdian adalah kurangnya pengetehuan mitra/khalayak sasaran terkait larangan rangkap jabatan bagi pegurus berdasarkan regulasi yang ada dalam hal ini rujukannya Permendagri Nomor 18 Tahun 2018, sehingga terjadi rangkap kepengurusan bahkan ada yang menjadi anggota maupun pengurus partai politik.

\section{Target dan Luaran}

Target kegiatan pengabdian kepada masyarakat ini adalah meningkat pengetahuan dan pemahaman pengurus Lembaga Pemberdayaan Masyarakat (LPM) se-kecamatan Kulim kota Pekanbaru larangan rangkap jabatan berdasarkan Peraturan Menteri Dalam Negeri Nomor 18 Tahun 2018 Tentang Lembaga Kemasyarakatan Desa dan Lembaga Adat Desa.

Luaran yang akan dihasilkan sesuai rencana kegiatan pengabdian kepada masyarakat ini adalah draft artikel ilmiah dan publikasi media massa (sesuai panduan buku pedoman penelitian dan pemngabdian kepada masyarakat yang berlaku di Universitas Lancang Kuning).

\section{METODE}

Metode pelaksanaan yang disepakati dengan pihak mitra sebagai berikut :

1. Ceramah atau penyampaian materi sesuai kebutuhan prioritas pihak mitra.

2. Materi Penyuluhan dibagikan kepada seluruh khalayak sasaran.

3. Dibuka sesi dialog interaktif, mitra/khalayak dapat bertanya jawab, memberi ulasan. Adapun partisipasi mitra dalam hal ini sebagai fasilitator yang memberikan persetujuan, menyediakan tempat dan memobilisasi peserta.

4. Evaluasi pelaksanaan dengan cara memberikan kuesioner awal sebelum materi disampaikan dan kuesioner akhir setelah kegiatan dilaksanakan, dengan tujuan mengukur tingkat pemahaman terhadap materi yang disampaikan, tingkat kehadiran diharapkan $65 \%$ dari $100 \%$ peserta yang di harapkan hadir.

\section{Kelayakan Tim Pelaksana}

Kepakaran yang dibutuhkan dalam menyelesaikan persoalan mitra adalah pakar Hukum Tata Negara, Hukum Pemerintahan Daerah, Hukum dan Politik Ketatanegaraan sebagaimana tabel tim pengusul berikut : 
Tabel 1. Kelayakan Tim Pelaksana Pengabdian

\begin{tabular}{|c|c|c|c|}
\hline No & Nama & Kepakaran & Tugas \\
\hline 1 & Dr. H. Eddy Asnawi, S.H., M.Hum & $\begin{array}{l}\text { Hukum Tata Negara, } \\
\text { Hukum Pemerintahan } \\
\text { Daerah }\end{array}$ & $\begin{array}{l}\text { Mengkoordinir dan } \\
\text { merancang agenda } \\
\text { kegiatan dan pembuatan } \\
\text { laporan }\end{array}$ \\
\hline 2 & Andrizal, S.H., M.H & $\begin{array}{l}\text { Hukum dan Politik } \\
\text { Ketatanegaraan, Teori } \\
\text { Perundang-Undangan, } \\
\text { Hukum Pemerintahan } \\
\text { Daerah }\end{array}$ & $\begin{array}{l}\text { Survey dan penjajakan } \\
\text { tempa kegiatan, } \\
\text { pengumpulan data dan } \\
\text { kelengkapan administrasi } \\
\text { serta analisa data }\end{array}$ \\
\hline 3 & Birman simamora, s.H., IV.H & $\begin{array}{l}\text { Hukum Tata Negara, } \\
\text { Hukum Administrasi } \\
\text { Negara }\end{array}$ & $\begin{array}{l}\text { Merancang Modul/ mater } \\
\text { kegiatan, Menyampaikan } \\
\text { Materi kegiatan }\end{array}$ \\
\hline
\end{tabular}

\section{HASIL DAN PEMBAHASAN}

\section{Hasil Pelaksanaan Kegiatan}

Permasalahan prioritas pihak mitra adalah, kurangnya pengetahuan dan pemahaman mengenai larangan rangkap jabatan pengurus Lembaga Pemberdayaan Masyarakat berdasarkan Peraturan Menteri Dalam Negeri Nomor 18 Tahun 2018 Tentang Lembaga Kemasyarakatan Desa dan Lembaga Adat Desa.

Pada saat pelaksanaan kegiatan berlangsung fenomena yang muncul berdasarkan hasil dialog interaktif dan respons khalayak sasaran, muncul suatu permasalahan yang dialami beberapa khalayak, pertama pertanyaan dari bapak Surono selaku ketua LPM kelurahan Kulim yang menanyakan bagaimana jika kepengurusan yang sudah terlanjur dibentuk ada yang menjabat sebagai ketua RT dan RW dilingkungan masing-masing. Kedua pertanyaan dari bapak Menhori selaku ketua LPM kecamatan Tenayan Raya yang bertanya mengapa pengurus LPM tidak boleh orang yang menjadi pengurus atau anggota partai politik. Maka pihak pengabdi menjawab pertanyaan keduanya secara bergantian, misalnya menjawab pertanyaan pertama, jika memang itu terjadi maka mesti ada revisi kepengurusan yang mesti dituangkan dalam sebuah surat keputusan kepengurusan yang baru, rangkap jabatan dengan jabatan lembaga kemasyarakatan desa lainnya memang dilarang. Jawaban untuk pertanyaan kedua, secara filosofis LPM sebagai salah satu lembaga kemasyarakatan desa mestilah diurus oleh orang-orang yang independen karena yang menyuarakan aspirasi masyarakat dan mitra kepala desa atau lurah dalam membangun kepentingan masyarakat banyak, jika dihuni oleh orang yang juga menjadi pengurus atau anggota partai politik tertentu besar kemungkinan justru akan membawa kepentingan partai politiknya baik secara langsung maupun terselubung.

Berdasarkan hasil yang diperoleh dari kegiatan ini para peserta telah merasakan manfaatnya, yaitu mendapat tambahan pengetahuan dan pemahaman tentang larangan rangkap jabatan bagi pengurus LPM dan tugas-tugas LPM, hal itu disimpulkan tim pengabdian kepada masyarakat setelah membandingkan hasil tes awal (pre test) dan tes akhir (post test) dengan cara mengajukan kuisioner sebelum dan sesudah pemberian materi.

Sebelum pemberian tes awal tersebut khalayak sasaran atau para peserta banyak yang tidak mengetahui dan memahami tentang hal tersebut diatas. Setelah dilakukan pengabdian kepada masyarakat dengan pemberian materi yang tepat maka khalayak sasaran pada umumnya mampu menjawab dengan benar pertanyaan-pertanyaan di dalam kuisioner yang diajukan 
setelah pelaksanaan kegiatan. Dengan demikian, kegiatan pengabdian kepada masyarakat ini dapat dikatakan telah berhasil dengan indikator perbandingan hasil tes awal (pre test) dan tes akhir (post test) kepada khalayak sasaran. Pelaksanaan kegiatan pengabdian kepada masyarakat ini dapat dikatakan tidak dijumpai hambatan dengan dihadiri puluhan pengurus karena tema yang diangkat cukup menarik dan relevan dengan konsidi LPM se-kecamatan Kulim saat ini.

Keberhasilan pelaksanaan kegiatan pengabdian ini dapat dilihat berdasarkan tabel hasil kuisioner pre-test dan post-test berikut :

Tabel 1. Hasil Kuisioner Pre-Test dan Post-Test

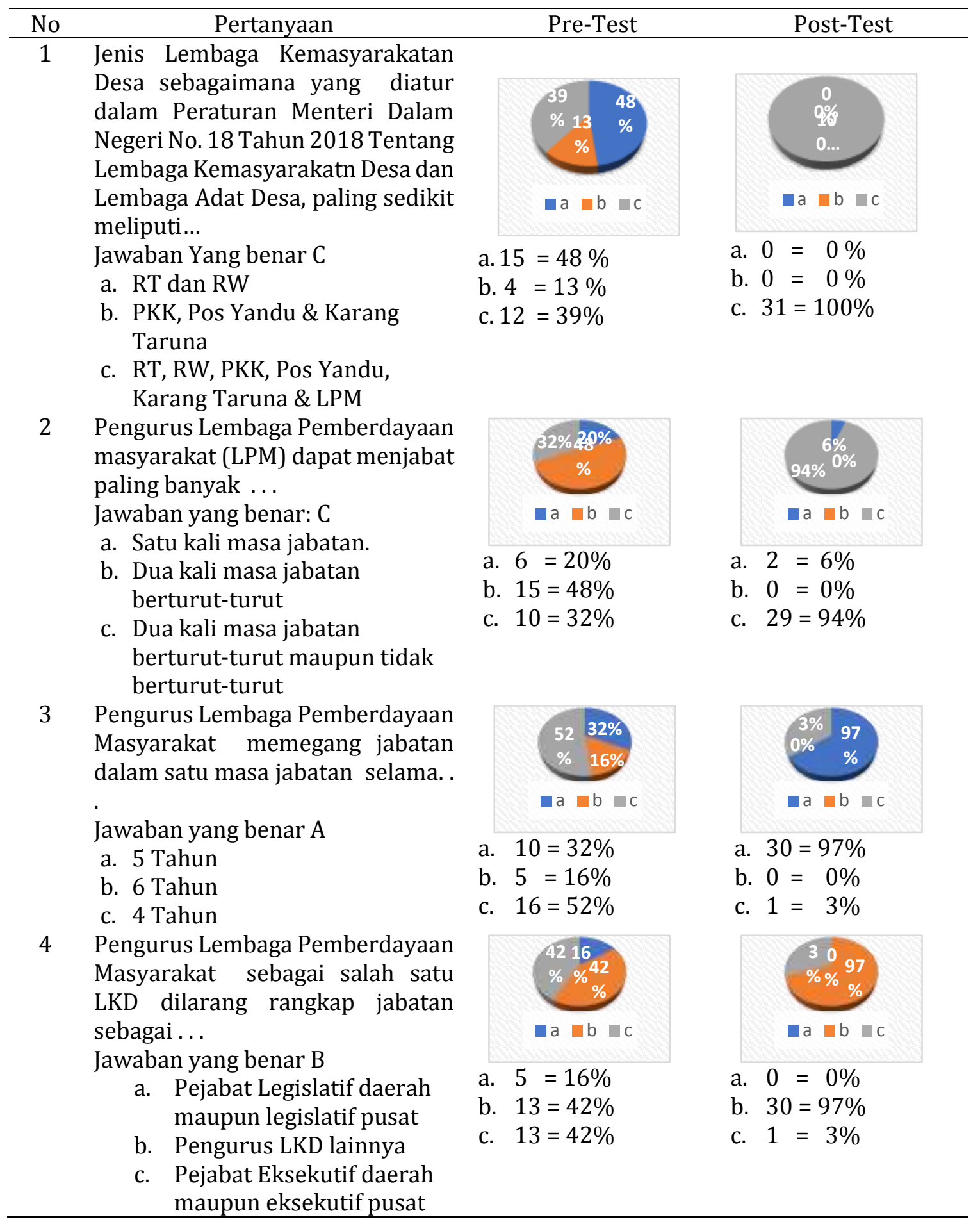



$5 \quad$ Pengurus Lembaga
Pemberdayaan Masyarakat juga
dilarang menjadi. .
Jawaban yang benar B
a. Pengurus rumah ibadah
b. Anggota salah satu partai politik
c. Anggota dan pengurus ormas keagamaan

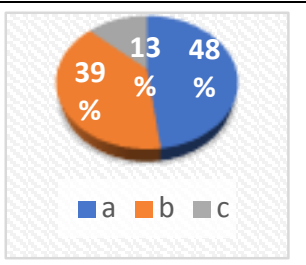

a. $15=48 \%$

b. $12=39 \%$

c. $4=13 \%$

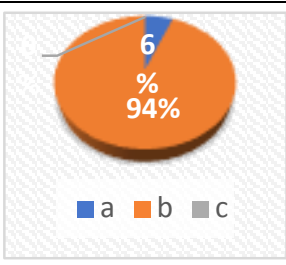

a. $2=6 \%$

b. $29=94 \%$

c. $0=0 \%$

Sumber Data : Mei 2021

Memperhatikan data pada tabel di atas nampak bahwa sebelum pemberian materi khalayak sasaran atau para peserta banyak yang belum mengetahui hal-hal yang telah di atur oleh Peraturan Menteri Dalam Negeri Nomor 18 Tahun 2018 Tentang Lembaga Kemasyarakatan Desa dan Lembaga Adat Desa.

Setelah pemberian materi terjadi peningkatan pengetahuan dan pemahaman khalayak sasaran berkisar antara 65\%-70\% dari sebelumnya, karena pada umumnya mereka memilih jawaban yang benar sebagaimana dapat dilihat pada tabel pre test dan post test diatas.

Luaran yang Dicapai

Luaran yang dicapai dan diharapkan dari kegiatan pengabdian ini adalah setelah khalayak sasaran meningkat pengetahuan dan pemahamannya tentang larangan rangkap jabatan bagi pengurus lembaga pemberdayaan masyarakat.

\section{KESIMPULAN}

Kegiatan Pengabdian kepada masyarakat ini dilaksanakan pada hari Sabtu, 29 Mei 2021 bertempat di salah satu Ruangan Kantor Camat Kulim. Kegiatan ini dimulai pukul 09.00 WIB sampai dengan 12.00 WIB. Jumlah peserta yang hadir berdasarkan absensi sebanyak 31 (Tiga Puluh Satu) orang.

Dari pelaksanaan kegiatan ini dapat diambil kesimpulan yaitu, Pemahaman khalayak tentang larangan rangkap jabatan bagi pengurus LPM sangat minim, hal ini dapat dilihat dari jawaban dalam kusioner peserta sebelum kagiatan dilaksakan. Setelah kegiatan dilaksanakan terdapat peningkatan yang sangat seignifikan dalam jawaban kusioner peserta meningkat.

Saran

Dari kesimpulan yang telah disebutkan di atas, maka timbul harapan dari tim, untuk mewujudkan harapan tersebut maka tim memberikan saran-saran sebagai berikut:

1. Pengabdian kepada masyarakat harus di arahkan kepada Penyuluhan Hukun baik berupa: Pelatihan, Seminar, dan Sosialisasi peraturan perundang-undangan, terutama undangundang yang baru disahkan

2. Dalam kaitannya dengan larangan rangkap jabatan dan banyaknya pengurus yang juga pengurus dan anggota partai politik tertentu mesti diterapkan.

\section{DAFTAR PUSTAKA}

Abdul Wahab, S. (1999). Analisis Kebijakan Publik Teori dan Aplikasinya. Malang: Danar Wijaya. Ibrahim, A. (2004). Pokok-pokok analisis kebijakan publik (AKP). Mandar Maju.

Nugroho, R. (2003). Kebijakan Publik, formulasi, Implementasi dan evaluasi. Jakarta: Elex Media Komputindo..

Subarsono, A. G. (2012). Analisis kebijakan publik: konsep, teori dan aplikasi.,

Suharto, E. (2015). Analisis kebijakan publik: panduan praktis mengkaji masalah dan kebijakan sosial. 
Undang-Undang Dasar Negara Republik Indonesia tahun 1945

Undang-Undang Nomor 6 tahun 2014 tentang Desa

Undang-Undang Nomor 23 tahun 2014 tentang Pemerintahan Daerah

Peraturan Pemerintah Nomor 43 tahun 2014 tentang Peraturan Pelaksana Undang-Undang Nomor 6 tahun 2014 tentang Desa.

Peraturan Menteri Dalam Negeri Nomor 18 tahun 2018 tentang Lembaga Kemasyarakatan Desa dan Lembaga Adat Desa.

Yandra, A. (2016). Partisipasi Masyarakat dalam Penyusunan Rencana Pembangunan Jangka Menengah Daerah (RPJMD) Kota Pekanbaru 2012-2017. PUBLIKA: Jurnal Ilmu Administrasi Publik, 2(1), 48-58. 